\title{
TENDENCES OF FORMING THE FUTURE PHYSICAL EDUCATION TEACHERS' SUBJECTIVITY
}

\section{ТЕНДЕНЦІї ФОРМУВАННЯ СУБ'ЄКТНОСТІ МАЙБУТНІХ УЧИТЕЛІВ ФІЗИЧНОї КУЛЬТУРИ}

УДК 378:796.071.4

DOI https://doi.org/10.32843/2663$6085 / 2021 / 34-2.8$

\section{Hurin R.S.,}

Candidate of Pedagogical Sciences, Associate Professor at the Department of Pedagogics

South-Ukrainian National Pedagogical University named after K.D. Ushynsky

\section{Yatsii O.M.}

Candidate of Pedagogical Sciences, Associate Professor at the Department of Pedagogics

South-Ukrainian National Pedagogical University named after K.D. Ushynsky

\section{Mamatova Z.R.,}

Lecturer at the Department of Defectology and Physical Rehabilitation

South-Ukrainian National Pedagogical University named after K.D. Ushynsky
The article is devoted to the analysis of the problem of forming the subjectivity of future physical education teachers during their professional development. It is determined that realization of the need for diverse comprehension, awareness and understanding of the future physical education teachers' attitude to a healthy lifestyle, organization of cognitive independence and innovative orientation to pedagogical activity in modern conditions of pedagogical education development have an impact on the indicators of their professional formation. The purpose of the article is to highlight the tendencies in forming the subjectivity of future physical education teachers during their professional development. The research methods were the next: analysis of modern normative-legal, methodical, psychological and pedagogical sources on the problem of training the future physical education teachers and systematization of scientific information on the content of the subjectivity construct. During theoretical and methodological analysis of the scientific fund it was established that subjectivity is defined as: pecularity that reveals the essence of the human way of life, which consists in a conscious and active attitude to the world and oneself in it, and also the ability to reproduce mutually conditioned changes in the world, other people, as well as in oneself; social, activity-transforming way of human entity; the presence of a unique professional "Self", in its uniqueness and creativity, in professional and volitional competence in teaching and pedagogical activities. The levels of health values are characterized. The essence and content of the construct "cognitive independence", as well as a number of advantages of distance learning in comparison with the traditional one, are considered. The following tendencies of forming the subjectivity of the future physical education teachers during professional development are defined, such as: organization of cognitive independence; valuable attitude to healthy lifestyle; innovative directive on pedagogical activities. Key words: subjectivity, future teachers, cognitive independence, healthy lifestyle, distance learning.

Статтю присвячено аналізу проблеми формування суб'єктності майбутніх учителів фрізичної культури під час про- фесійного становлення. Визначено, що реалізація потреби в різнобічному осмисленні, усвідомленні та розумінні майбутніми вчителями фрізичної культури ціннісного ставлення до здорового способу життя, організація пізнавальної самостійності та інноваційне спрямування на педагогічну діяльність у сучасних умовах розвитку педагогічної освіти впливають на показники професійного становлення. Метою статті є визначення тенденцій формування суб'єктності майбутніх учителів фрізичної культури під час професійного становлення. Методами дослідження виступили: аналіз сучасних нормативно-правових, методичних, психолого-педагогічних джерел із проблеми підготовки майбутніх учителів фрізичної культури та систематизація наукової інсрормації щодо змістовного наповнення конструкту суб'єктності. Під час теоретико-методологічного аналізу наукового фонду встановлено, що суб'єктність визначають як: властивість, яка розкриває сутність людського способу буття, що полягає в усвідомленому і діяльнісному ставленні до світу і себе в ньому, і здатність відтворювати взаємозумовлені зміни у світі, інших людях, у собі; соціальний, діяльнісно-перетворювальний спосіб буття людини; наявність неповторного просесійного «Я» в його унікальності та творчості, у профресійній і фраховій компетентності в педагогічній справі та педагогічній діяльності. Охарактеризовано рівні чінностей здоров'я. Розглянуто сутність та змістовне наповнення конструкту пізнавальна самостійність, а також низку переваг дистанційного навчання у порівнянні з традиційним. Визначено такі тенденції формування суб'єктності майбутніх учителів фрізичної культури під час профресійного становлення, як організація пізнавальної самостійності; ціннісне ставлення до здорового способу життя; інноваційне спрямування на педагогічну діяльність.

Ключові слова: суб'єктність, майбутні вчителі, пізнавальна самостійність, здоровий спосіб життя, дистанційне навчання.
Problem statement in general and its connection with important scientific or practical tasks. The relevance of the study is connected to the training of competitive physical education teachers, which enables the implementing of the National Strategy for Educational Development in Ukraine for 2012-2021, the Concept of Continuing Teacher Education (2013) and the Concept of Educational Development in Ukraine for 2015-2025. The former result in reformational changes that make certain demands on the personality of the contemporary physical education teacher, modernization and quality of his / her professional training on the basis of innovative strategies. This raises the attention to the individuality of the future physical education teachers and proves that high level of subjectivity can be one of the most important indicators of their professional development. In this regard, the need for diverse comprehension, awareness and understanding of the future physical education teachers' valuable attitude to a 
healthy lifestyle, organization of cognitive independence and innovative directive on teaching activity in the recent conditions of pedagogical education is not in doubt.

Analysis of the recent studies and publications. There can be found a number of scientific studies in modern pedagogy, which considers various aspects of the concept «subject» (A. Adler, B. Ananiev, M. Berdyaev, A. Derkach, E. Erickson, V. Frankl, K. Levin, S. Rubinstein, and others) and «subjectivity» (K. Abulkhanova-Slavskaya, A. Brushlinsky, O. Leontiev, A. Markov, F. Mukhametyaznov, A. Petrovsky, V. Shadrikov, V. Slobodchikov, O. Volkova, V. Yagupov, etc.) within the philosophical, sociological and psychological areas. Despite the sufficient number of psychological and pedagogical research: M. Agulov, 2010 (Psychological factors of the dynamics of the future teacher's subjectivity in the learning process); Z. Adamska, 2010 (Psychological and pedagogical grounds of the future psychologists' subjectivity development); S. Dyakov, 2006 (Semantic factors of the future teacher's subjectivity); L. Ivantsev, 2003 (Formation of the future teacher's personality as the subject of life creation); O. Lehun, 2005 (Development of the teacher's subject orientation subject interaction in the process of postgraduate studies); S. Pelipchuk, 2007 (Pedagogical conditions of the future lawyers' subjectivity formation in the process of studying psychological and pedagogical disciplines); M. Ryabenko, 2007 (Preparing the future teacher as a subject of educational legal relations); O. Tsymbal, 2011 (Psychological and pedagogical conditions of the student's subjective position formation in the process of studying the disciplines of pedagogical cycle); N. Yaksa, 2009 (Future teachers' professional training for interaction of the educational process subjects in the conditions of the Crimean region multiculturalism) the question of forming the future physical education teachers' subjectivity during professional development remains open.

Highlighting of previously unsolved parts of the general problem. The training of a modern physical education teacher must consider the relevant tendencies for the formation of his / her subjectivity during professional development and correspond to the realities of today. Despite the availability of scientific research on this problem, it is necessary to study the theoretical foundations of the future physical education teachers' subjectivity formation. Of particular significance is the question of organizing cognitive independence, valuable attitude to a healthy lifestyle and innovative directive on teaching activities during their subjectivity formation.

Formulation of the goals of the article (task statement). The purpose of the article is to highlight the current tendencies in the formation of the subjectivity of future physical education teachers during their professional development. To achieve this goal, the following research objectives were set: to clarify the concept of «subjectivity»; to characterize the tendencies that determine the formation of the future physical education teachers' subjectivity during their professional development.

Presentation of the main research material. Considering the scientific category of "subjectivity", it was found out that the versatility of the study affects the ambiguity of its terminology. Scientists define subjectivity as: pecularity that reveals the essence of human way of life, which consists in a conscious and active attitude to the world and oneself in it, and the ability to reproduce interdependent changes in the world, other people, oneself [2]; social, activity-transforming way of human existence, as self - subjectivity is an obvious and directly given form of human existence [12]; the presence of a unique professional "Self", in its specificity and creativity, in professional and volitional competence in both teaching and pedagogical activities.

Note that teacher's subjectivity is related to the individual's ability to transform their own lives, pedagogical activities into a subject of practical transformation and improvement. The essential pecularities of this process are as follows: goal-setting of one's own professional and personal development as well as of oneself as a regulator of these processes; selecting, finding and producing the psychological and pedagogical tools to achieve this goal; making decisions to achieve the goal as much as possible under any possible conditions; implementation of decisions; valuation of results and analysis of the degree of success achieved; accumulation of individual experience, fixation of results and ways of development of proper subjective qualities [8].

Modernization of the system of vocational education at higher educational institutions consists in creating a developmental pedagogical system based on the active use of innovations and innovative technologies in the educational environment and allows to achieve the required quality of training physical education teachers. Innovative technologies in the training of future physical education teachers are aimed at improving the efficiency of the educational system and its entry into a qualitatively new level of functioning and should be based on understanding the essence of psychological and pedagogical training at higher educational institution as a system, process, activity and result - training of socially active, competent physical education teachers with developed pedagogical mastery, able to act creatively in accordance with educational tasks of secondary schools and other institutions [11]. This encourages a deeper analysis of the problems of forming the future physical education teachers' valuable attitude to healthy lifestyle, the organization of cognitive independence and their innovative directive on teaching activity during professional development. 
Lifestyle changes and the formation of the need for a healthy lifestyle as well as for the possibility of real control and health accounting, especially during «Covid-19», are of particular scientific interest. Despite the sufficient number of psychological and pedagogical research in the field of the culture of health and valuable attitude towards it (N. Abaskalova, I. Bekh, N. Biryukov, B. Bratus', I. Hlynyanova, I. Ilyina, L. Tatarnikova, M. Vilensky, I. Yakovlev, etc.) the question of forming the future physical education teachers' valuable attitude to a healthy lifestyle remains open. Analysis of the scientific fund (B. Ananiev, I. Bekh, E. Bondarevska, L. Bozhovych, N. Chepeleva, V. Isayev, V. Lykova, S. Maksymenko, V. Semichenko, T. Tytarenko, etc.) reveals the non-availability of a unified approach to the problem of values. However, different definitions, classifications of valuable orientations and values do not contradict, in general, to each other, but complement each other and allow to consider them from different positions.

Considering the classification of professional and pedagogical valuable orientations, it was found out that the reflection of the specifics of the teaching profession occurs in: general-pedagogical orientation, aimed at social values of the pedagogical profession; personal-developmental orientation associated with the child's personality development as the main pedagogical value; subject-activity orientation aimed at teacher's subject-teaching activity; personal orientations aimed at teacher's self-expression in professional activity; professional-pragmatic orientation associated with the prestige of the teaching profession, wages, long vacations, etc. [6].

Based on the subject of the study, we note that, firstly, the scientists distinguish three levels of health values: biological (physical) - health as the system of the body that self-regulates and adapts; social health as individual's measure of social activity; and mental health not as the absence of disease, but as the strategy to overcome it [1]. Secondly, the healthy lifestyle is considered as one of the human values, which is aimed at understanding the meaning of these phenomena and the development of the future teachers' ability to understand healthy lifestyle as a significant phenomenon for them, because the core issue in a healthy lifestyle is active health creating. It should be noted that the complex structure of a healthy lifestyle (physical, mental, spiritual and intellectual spheres of human life) does not allow to refer it to any one of the classes of values. As rightly noted by $\mathrm{O}$. Plaksina, a healthy lifestyle is a terminal value (goal), as well as an instrumental value (a means of maintaining health), which indicates the complex nature of the concept of a healthy lifestyle and confirms the thesis of the possible transition of values-goals into value-means. Thus, on the one hand, healthy lifestyle as a terminal value initiates the formation of the need for a healthy life, and on the other - as an instrumental value it serves as a means to achieve health. The valuable attitude to a healthy lifestyle is defined as a result of a purposeful and multifaceted process of forming students' knowledge about healthy lifestyle, abilities and skills of adhering to it, fostering the sense of responsibility for their own lives and health [10].

In view of this, we conclude that the necessity to form valuable attitude of the future physical education teachers to a healthy lifestyle during professional development is not in doubt.

Intensive introduction of modern IT technologies into all the spheres of human life has also changed the role of teaching, learning, values, information transfer in particular. Such changes imply the importance of education for the individual, the focus of learning on the individual and on providing the opportunities for self-disclosure. Considering the construct «cognitive independence», it should be emphasized that the versatility of its investigation affects the ambiguity of the terminological design of the concept, which has a number of synonymous definitions in science, associated with activity, individual potency and creativity. The indicators of cognitive independence include: the ability to work independently with different sources of information, to apply the acquired knowledge in practice; the presence of cognitive interest, internal motives for learning, the need to enrich knowledge [5]. We fully agree with the author's team led by $\mathrm{N}$. Huziy, that cognitive independence includes motivational, semantic and procedural components, the formation of which will allow the future teachers to be able to think independently, see the problem and ways to solve it, orientate in a new cognitive situation, etc. [13].

Theoretical analysis of research by S. Honcharenko, P. Pidkasisty, I. Zymna and others made it possible to establish that the concept of cognitive independence is identified with individual work and is seen as the ability of those who study to organize their own cognitive activity and implement it in solving a new cognitive problem, as well as in the need and ability to master the knowledge and methods of activity, readiness to solve cognitive problems without direct assistance, to determine the objectives of the activity and adjust them timely.

Note that the realities of today require the use of distance learning in the educational process during the development of the future teachers' cognitive independence. On the other hand, the organization of individual work of higher education applicants is impossible without applying distance learning technologies.

Theoretical and methodological principles of distance learning are substantiated by $\mathrm{V}$. Bykov, H. Dychkivsky, R. Hurevych, O. Khmel, A. Khutorsky, K. Kovalska, Y. Linnyk, L. Lyakhotska, N. Morse, 
V. Oliynyk, E. Smirnova-Trybulska, V. Tikhomirov, Y. Trius, M. Zhaldak, and others.

Distance learning has a number of advantages over traditional learning: advanced educational technologies, availability of information sources, individualization of learning, convenient counseling system, democratic relations between the student and the teacher, convenient schedule and place of work [7]. It should be noted that with the development of modern software and hardware of information technology, both forms and methods of distance learning are undergoing significant changes.

Summing up, we conclude that organization of cognitive independence of the future physical education teachers should be based on applying distance learning technology in the educational process, during which there is a strengthening of their active role in their own education, namely: in setting educational goals, selecting of dominant areas, forms and rates of learning in various educational fields; a sharp increase in the amount of available educational resources and cultural and historical achievements of mankind; getting the opportunity to communicate with teachers, associates; advising with high-level specialists regardless of their territorial location; increasing the heuristic component of the educational process through the use of interactive forms of classes, conducting multimedia training programs [5].

Modernization of the content of the future physical education teachers' professional training is associated with a number of circumstances, namely: socio-economic transformations that lead to the need for radical renewal of the education system, methods and technology of educational process at the educational institutions of various types. Innovative orientation of teachers and educators, that combines the creation, developing and testing of pedagogical innovations, is also an effective means of updating the educational policy; strengthening of humanization of the education content, continuous change in the volume and composition of academic disciplines; introduction of new subjects that require constant search for new organizational forms, learning technologies; changing teachers's attitude to the very fact of development and application of pedagogical innovations. In terms of strict regulation of the educational process content, the teacher was limited not only in the individual choice of new programs, textbooks, but also in the use of new techniques and methods of teaching [9]. Therefore, today it is the innovative activity in education that acquires a selective, investigative character; the entry of educational institutions into market relations, the creation of new types of educational institutions, including those private, which form the real situation of their competitiveness. Thus, taking into account the highlighted factors, it should be noted that the use of innovation in education is a natural process caused by social demand and con- ditioned by necessity of its improving and revising its content and structure [4].

In the process of investigating the abovementioned problem, it was proved that innovative training of the future teachers should be aimed at their emergence as subjects of educational innovations and provide preparation for: successful introduction of innovative and personality-oriented education technologies into the educational process of secondary schools; forming the pupils' key competencies of a united Europe citizen, information society and a democratic state with a market economy; creation of educational innovations, their scientific substantiation and experimental verification; implementation of a scientifically well-grounded assessment of various educational technologies, methods, etc., making a professionally balanced decision on the appropriateness of their use in their own professional activities; spreading of educational innovations in the pedagogical community [3].

Conclusions. Based on the results of the scientific fund analysis of the phenomenological feature of subjectivity and taking into account the originality of the content of modern training in terms of its formation in the future teachers of physical education such tendencies were identified as: organization of cognitive independence; valuable attitude to a healthy lifestyle; innovative directive on pedagogical activities. The prospect for further research in this direction will be to develop an experimental model for implementing the pedagogical conditions of the future physical education teachers' subjectivity formation during their professional development.

\section{REFERENCES:}

1. Виленский М.Я., Масалов О.Ю. Феномен ценности здоровья в развитии личности студента. Педагогика здоровья. 2009. № 2. С. 2-7.

2. Волкова Е.Н. Субъектность педагога : теория и практика : автореф. дис. ... д-ра психол. наук : 19.00.07. Москва : Психол. Ин-т РАО, 1998. 50 с.

3. Гавриш І.В. Теоретико-методологічні основи формування готовності майбутніх учителів до інноваційної професійної діяльності : автореф. дис. .. д-ра пед. наук : 13.00.04. Луганський національний педагогічний університет імені Т. Шевченка. Луганськ, 2006. 46 c.

4. Гринченко І. Інтеграція інновацій в процес профресійної підготовки майбутніх учителів фрізичної культури. Наукові записки Кіровоградського державного педагогічного університету імені Володимира Винниченка. Серія : педагогічні науки. 2012. № 112. C. 149-157.

5. Гурін Р.С. Організація пізнавальної самостійності майбутніх учителів. Perspectives of world science and education (September 9-11, 2020) : abstracts of the 13th international scientific and practical conference. Cpn publishing group. Osaka, Japan. 2020. P. 99-102.

6. Денисенко В.В. Формування ціннісних орієнтацій майбутніх учителів початкових класів : авторефр. дис. ... канд. пед. наук : 13.00.04. Харків, 2005. 19 с. 
7. Долинський Є.В. Дистанційне навчання - одна 3 прогресивних фрорм підготовки фрахівців. Теоретичні питання культури, освіти та виховання : збірник наукових праць. Вип. 42 / за заг. ред. профр. Матвієнко О.В. Київ : Вид. центр КНЛУ, 2010. C. 202-207.

8. Кашлев С.С., Глазачев С.Н., Соколова Н.И. Субъектность как профессиональная компетентность педагога. Вестник международной академии наук - специальный выпуск. 2011. С. 25.

9. Огієнко О. Формування готовності до інноваційної діяльності як важлива складова професійної підготовки майбутнього вчителя. Педагогічні науки : теорія, історія, інноваційні технології. 2013. № 7. С. 154-162.
10. Плаксина О.А. Формирование ценностного отношения к здоровому образу жизни у студентов педагогических специальностей университета : автореср. дис. ... канд. пед. наук : 13.00.01. Рязань, 2008. 24 с.

11. Степанченко Н.І. Система профресійної підготовки учителів фрізичного виховання : монографрія. Львів : Піраміда, 2016. 652 с.

12. Татенко В.А. Психология в субъектном измерении : монография. Киев : Просвіта, 1996. 404 с.

13. Теорія та методика професійно-педагогічної підготовки освітянських кадрів : акмеологічні аспекти : монографрія / керівн. авт. кол. Н. В. Гузій. Мін-во освіти і науки України, Нац. пед. ун-т імені М. П. Драгоманова. Київ : Вид-во НПУ імені М. П. Драгоманова, 2018. 516 c. 